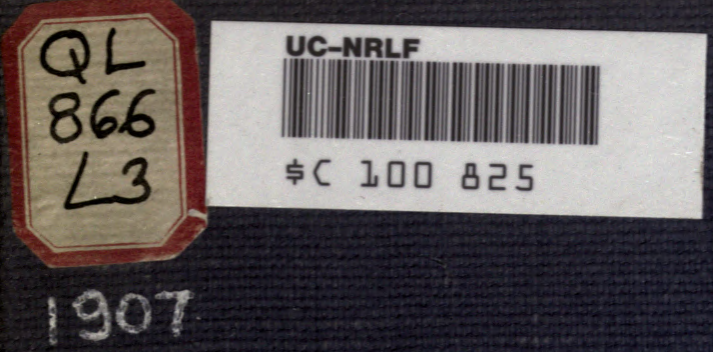



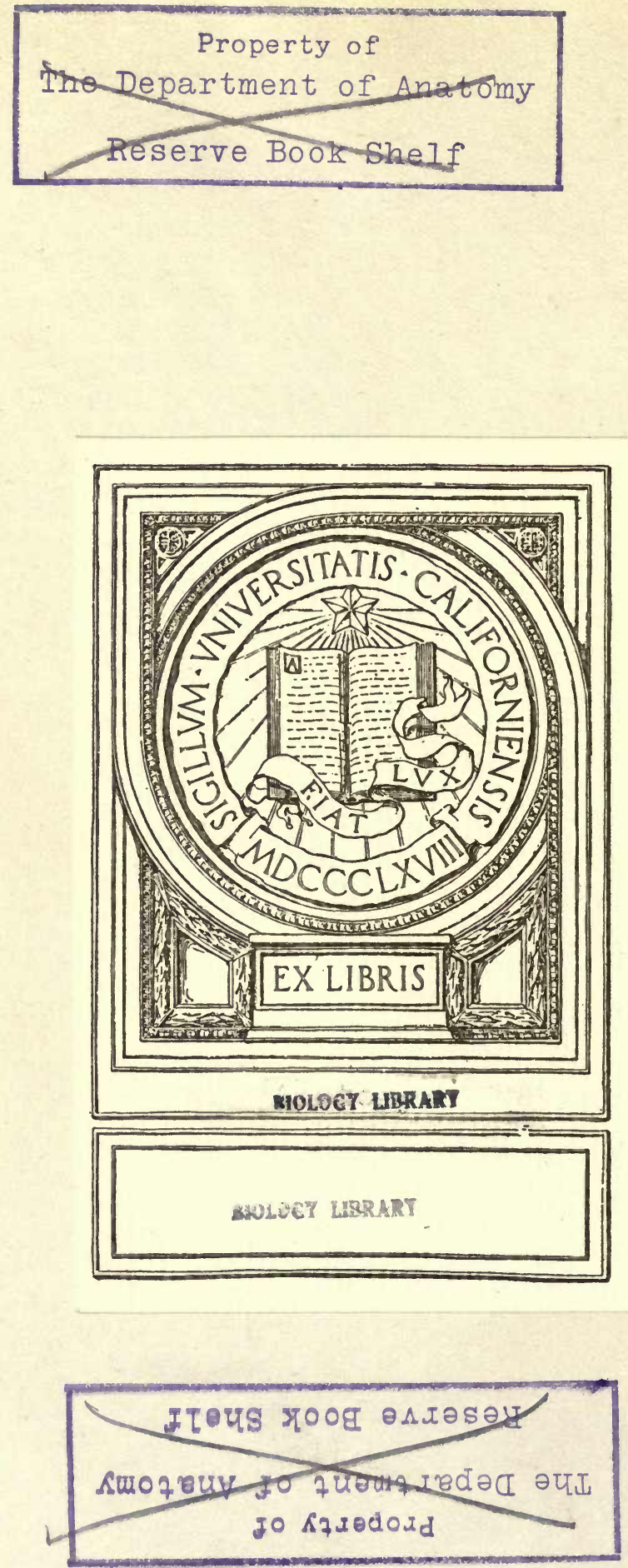





\title{
THE CYTOLOGICAL CHARACTERS OF THE AREAS OF LANGERHANS
}

\author{
BY \\ M. A. LANE \\ From Hull Laboratory of Anatomy, University of Chicago \\ WITH 1 PLATE
}

Reprinted from ThI AMERICAN JotRNiL OF ANATOMY, Vol. VII, No. 3, pp. 409-422 NOVEMBEB 10,1907 


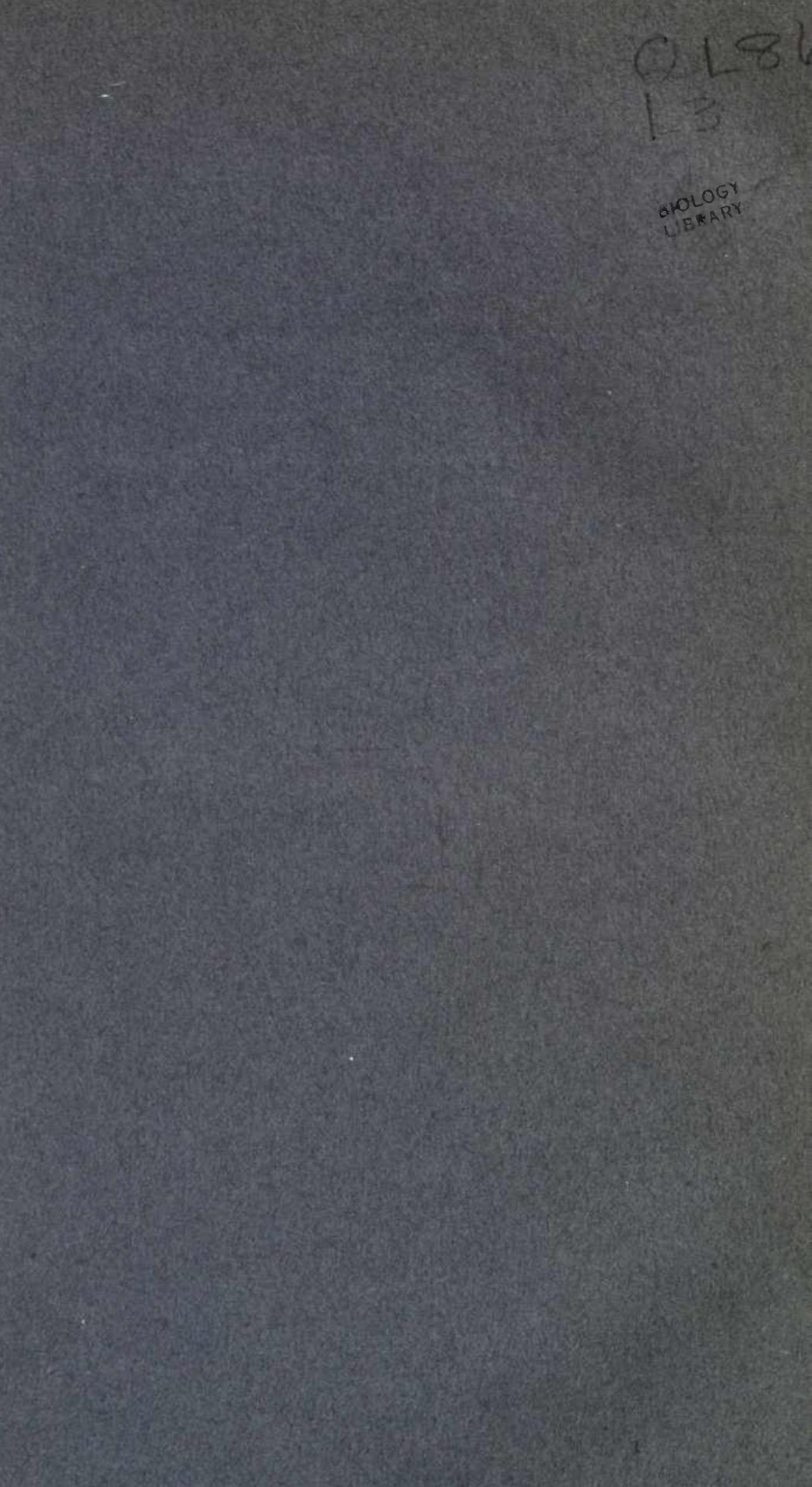




\title{
THE CYTOLOGICAL CHARACTERS OH THE AREASS OF
} LANGERHANS:

BY

\author{
M. A. LANE.
}

From Hull Laboratory of Anatomy, University of Chicago.

With 1 Plate.

In the course of a comparative study of the pancreas, begun in the autumn of 1905 , I was struck with a peculiar reaction in certain cells of the Islets of Langerhans in the pancreas of the guinea pig-one of the first animals used in the study. This reaction,- - to be described presently, -indicated the existence in the islets of two types of cells, chemically and morphologically different from each other. A part of the ensuing investigation is the subject of the present paper, which is to be followed by a further publication dealing in detail with a comparative study of the islets which I have carried on side by side with that of the islets in the guinea pig.

The principal difficulty thus far in dealing with the Islets of Langerhans has been the want of a definite method by which to distinguish the cells of the islets from the cells of the pancreas itself; for although there is an apparently constant content of islet tissue in the pancreas, and although the areas of islet tissue, in sectioned pancreas, stand out in sharp contrast with the tubules of the pancreas, the physiological distinctness of the one kind of tissue from the other is the very question upon which histologists and pathologists have most disagreed. Pancreas cells exhausted by stimulation with alkaloids, and thus thoroughly discharged of their secretion products, have thus far been indistinguishable-so far as positive evidence goes-from cells of the islets; so that it has been impossible to say that exhausted cells which are indisputably pancreas cells are not essentially the same as islet cells; and, on the other hand, that cells which are indisputably islet cells are not in reality exhausted cells of the pancreas. To establish a method of differentiation between these two orders of cells was a purpose which thrust itself forward very early in the work, as the establishment of such a method would go far toward testing the claims of the two leading theories respecting the meaning of the islets.

American Jodrnal of Anatomy.-Vol. VII. 
The adherents of one of these theories have consistently held that the islets produce a substance which, in one or another way, controls carbohydrate metabolism. This view, so carefully considered and so capably studied by :0pie (14): has: a: particular significance when looked at in the light of my own experimrents on the chemism of the islets, especially

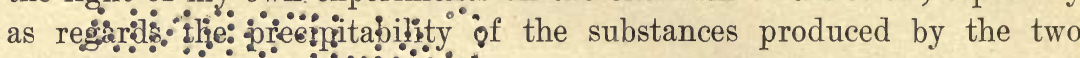
types of cells mentioned äbove. "What may be called the "sugar function" of the islets broadly suggests the outright physiological independence of the islets, and sharply marks off this view from that of the other party, the adherents of which have long urged the probability that the islets are merely exhausted acini which, as such, have no active function whatsoever, but are, so to speak, in a state of rest, or obscuration, and, at the end of the cycle, return to the active state as typical pancreatic acini. These being the two main interpretations of the islets, a demonstration that the cells of the islets have a chemical value of their own (and are not, as a matter of fact, merely exhausted pancreas cells, but cells which, whatever may have been their former state, have, as islet cells, a positive function) would seem to be indirectly confirmatory of the sugar theory, or confirmatory at least of the broader notion that the islets have an independent physiological activity of their own. Such confirmatory evidence, I believe, will be found in the various chemical tests described below.

- A few words of history, bearing particularly on these considerations, are necessary here. For a larger historical review the reader is referred to Oppel (13) and to Sauerbeck (19). The latter has an ample review of the pathological as well as of the anatomical literature of the islets. "

The structures called the Islets of Langerhans were discovered by Langerhans (10), who first called attention to them in 1869. The same year (subsequently to Langerhans's announcement) the name 'Les ilôts de Langerhans' was applied to them by Laguesse. Kühne and Lea afterwards gave them the name of "intertubular cell clumps." They have been called secondary cell groups (by Harris and Gow), points folliculaires (by Renaut), and Islands of Langerhans (by American anatomists).

The history of the islets from the date of their discovery until 1886 is chiefly interesting for the controversies it contains, and for the opinions hazarded as to the nature and function of the structures. Langerhans himself believed them to be the end-apparatus of nerve fibers. Renaut (17) described them in a very general way, and was unfortunate in being misquoted by some earlier writer who, since Renaut's announcement in 1879 , has been extensively followed throughout the whole of the 
literature - a fact to which Sauerbeck also calls attention. Renaut has been represented as saying that the islets were lymph structures. This is not so. He did not say they were lymphoid tissue-a misconception arising from the title of his paper. He simply made a note of their existence, at the same time remarking that they had not been described before. His only reference to lymph tissue in this paragraph of his paper is to the effect that the islets (called by him points folliculaires) were of the size of a lymphatic follicle.

Other writers hazarded other notions without, however, coming to any satisfactory conclusion. The first definite step in that direction was taken by Lewaschew (11) who, after considerable experiment with mammals, suggested that the islets were temporarily exhausted acini which, after a period of rest, resumed the acinous form. This theory would imply a continuous transformation of acini into islets, together with a disappearance of the lumen of the acinus; and, again, a continuous transformation of islets into acini, with an accompanying rebuilding of the lumen, together with the entire complex of changes in the form of the cell, in the nucleus and its content, in the arrangement of the glomerulus of the islet capillary system, and in whatever other changes that might be necessary in this peculiar process.

Lewaschew's theory further implies that these transformations are continually going on in the entire substance of the pancreas, and he urges, in point of probability that the islet cells are in continuity with the cells of the acini. Rennie (18) has studied peculiar structures in fishes which he identifies with the islets of Langerhans, although these structures lie remote from the pancreas in the abdominal cavity. Generalizations, however, concerning the islets in other animals based upon the existence of these isolated structures in fishes, await the results of Rennie's experimental work. Lewaschew's description of transitional cells, intermediate between typical islet and the typical acinus cells is very obscure, and the obscurity is only deepened by the uncolored drawings with which his paper is illustrated. Lewaschew's views, however, have been widely accepted and still have a considerable following. Dale (2) urges them as probable from his experiments on the toad by stimulation with " secretin," although the embryological studies of Helly (6), Opie (15), and Pearce (16) seen to point the other way.

Laguesse (7) investigated the islets of Langerhans in vipers from the histological point of view, and (8) the islets in the sheep from the histogenetic point of view. His work, in these respects, has brought to the study of these structures much of the most interesting matter thus far published. Laguesse did not distinguish two types of cells, but he (as 
well as others) observed the fact that the cells of the islets contained granules which could not be considered as artifacts, but were properly to be regarded as products of the metabolism of the cells themselves. He argues that the granules are not artifacts because

(a) The cells are literally crowded with brilliantly stained (safranin or gentian violet) granules.

(b) In the living structure the granules are also present when examined in serum.

(c) They are analogous (1) in their arrangement, (2) in their refraction, (3) in their brown coloration with osmic acid, and (4) in their vivid red coloration with safranin, to zymogen granules, and

(d) They are soluble in acetic acid.

Considering these facts in connection with the results of his histo genetic study of the islets in the pancreas of the sheep, he concludes that the islet and the acinous cells are transformable one into the other, as he gathers, also, from his studies of the embryo sheep alone. He believes that the islets normally furnish an internal secretion to the pancreas, but have the property of alternation from internal to external secretion, the former predominating. In the viper there are (1) secondary islets, scattered throughout the gland; developed from acini they return again to acini; and (2) permanent islets which, developed directly from the embryonic pancreatic tubes and not from acini, have no tendency to transformation into acini. But in the sheep they are atrophied, for the greater part, at a certain stage in their development, and are eliminated; in the viper they tend to persist to maturity. Laguesse finds vestiges of lumina among the cell-cords of the islets in vipers. From the above it will be seen that Laguesse coincides (with certain modifications) with the speculation of Lewaschew.

Flint (5) has studied the islets with a view of demonstrating the presence of a reticular capsule, and De Witt (3), in the course of an important experimental study of the islets, has constructed very handsome models of these structures showing their structural independence, and has furnished experimental evidence of the presence in the islets of the activator substance of Cohnheim.

The presence of granules in the islet cells was observed, as we saw above, by Laguesse; and Diamare (4) called attention to large granular, deeply staining cells in the islets of the rabbit's pancreas. W. Schulze (20) called attention to similar cells in the islets of the guinea pig's pancreas, and Mankowski (12), who repeated Schulze's work, found that on ligature of the pancreas the epithelial elements disappeared. Mankowski, however, found that an injection of silver nitrate disclosed certain 
black specks in the islet cells of the guinea pig; a fact indicating the presence in the islet cells of a substance which unites with silver in a reducible form, which does not occur-so far as Mankowski's experiments show-in the pancreas cell itself. These indications, however, were not pursued farther by any of the above-mentioned observers. Negative results as to granules were found by Hanseman, Stangl, and Ssobelew, although Mankowski, however, confirmed Laguesse's observations of granules in the islets (of the guinea pig's pancreas) after fixation in Flemming's fluid. References to the publications of these observers will be found in Sauerbeck's review above mentioned.

\section{Technique.}

Out of a rather wide range of fixing and staining fluids, three fixations and one stain were found to be the most valuable in the present investigation. The fixations used were (1) alcohol-chrome-sublimate, a fluid consisting of equal parts of a solution of potassium bichromate (3.5 per cent in water) and a saturated alcoholic (95 per cent) solution of mercuric chloride; (2) 70 per cent alcohol; and (3) Mueller's fluid with 5 per cent mercuric chloride added-a fiuid called here aqueous-chrome-sublimate. Very small pieces of the pancreas (preferably from the splenic end) are taken from the living animal and quickly transferred to a generous quantity of fluid. For small pieces two hours (with one change) is sufficient in the alcohol-chrome-sublimate fluid. Tissues are left in the 70 per cent alcohol twenty-four hours. In the aqueous-chrome-sublimate from three to four hours is sufficient. It is of the utmost importance in all this technique that acetic acid be carefully avoided, as I have found that even a few drops of this acid, after repeated trials with numerous fluids containing acetic acid, were enough to vitiate the entire work. The tissues, after fixation, were hardened in the customary graded alcohols, cleared in bergamot oil, and imbedded in paraffin. Sections were cut three to five micra thick and were fixed to slides by the water method. Out of a score of stains I found the most effective to be Bensley's neutral gentian, I. To a saturated aqueous solution of gentian violet is added a saturated equeous solution of orange G. The acid dye precipitates the basic one. This is filtered and thoroughly washed and dried. The precipitate is dissolved in 25 or 30 cc. of absolute alcohol. For staining purposes enough of this stock solution is added to 20 per cent alcohol to color the alcohol solution a deep violet.

The sections were stained 25 hours in this stain, blotted quickly and thoroughly with thick blotting paper or several sheets of filter paper in 
a pad, and two methods of differentiation were used. In the first method the slide, instantly after blotting, was douched with absolute alcohol from a medicine dropper to dissolve the excess of the stain, the alcohol quickly blotted off, and the sections instantly covered with oil of cloves. The differentiation was then watched under the microscope until the zymogen granules in the acinous cells were seen to be fairly discrete, the violet stain being differentiated out of the cytoplasm which, with this method, retains the brownish-yellow of the orange G. In the second method the sections were quickly blotted, as before, and the differentiation done with acetone (dimethylketone). The sections were douched with acetone from a medicine dropper, quickly placed under the microscope, and when the zymogen granules appeared, as before, the slide was placed in xylol. Xylol was also used for the final clearing of the alcohol-differentiated sections. The sections were then mounted in Canada balsam.

\section{Chemical Characters.}

The first sections examined were those fixed in alcohol-chrome-sublimate. This fixation is an admirable precipitant of the zymogen granules in the pancreas cells, but it has the disadvantage of shrinking the tissues somewhat. The granules of zymogen in the acinous cells are discrete and handsomely stained by the dye. The islet cells are somewhat shrunken, the majority of them taking up the yellow of the orange $\mathrm{G}$. In the center of the islet, sometimes eccentrically placed, and seldom near the edges, were seen a number of conspicuous and brilliantly violet cells, apparently much larger than the remaining cells of the islet and must frequently seen in a sharply defined group (Fig. 1). They seldom appear scattered or isolated. Examined with powers which distinctly show the individuality of the zymogen granules, the large violet cells of the islet appear to be of a diffuse color; but when examined under $2 \mathrm{~mm}$. apochr. these cells are found to be filled with granules very much smaller than the zymogen granule of the pancreas, but quite distinct none the less. The nuclei are large and vesicular, and at times surrounded by a very narrow clear zone in which there is seen occasionally a centrosome. The remaining cells of the islet, considerably more numerous than the cells reacting to the violet stain, show no granules in the cytoplasm, are smaller than the granular cells, and present other morphological characters which differentiate them from the latter. I will recur to these matters presently.

Preparations Fixed in 70 Per Cent Alcohol.-The presence of granules in certain of the islet cells, simultaneous with the presence of similarly reacting granules of zymogen in the acinous cells, suggested the query 
whether or not the chromatophile granules of the islet cells were zymogenic; whether or not the use of a reagent which would be a solvent forzymogen would nevęrtheless act as a precipitant for the granular substance in the islet cells. This experiment was made with alcohol of 70 per cent strength. Small pieces of pancreas of the guinea pig were fixed, therefore, in 70 per cent alcohol and stained with neutral gentian. In sections treated in this way the acinous cells were quite devoid of zymogen granules except at the extreme edge of the piece, where a partial fixation of the granules was obtained, whereas the islets presented the same appearance as in the sections fixed in the alcohol-chrome-sublimate. The same groups of violet-granulated cells were present. But, as the alcohol had not dissolved out the prozymogen of the acinous cell, the query still remained whether or not the substance in the islet cell granule partook of the nature of prozymogen. To check this query I applied MacCallum's iron reaction on these sections and failed to bring out the slightest trace of Prussian blue in the suspected cells of the islets, except in the nuclear chromatin.

Preparations Fixed in Aqueous-Chrome-Sublimate.-The use of this fluid I found advisable after exhausting the list of desirable acetic fixations and reducing the quantity of acetic acid to an almost negligible proportion. Sections from tissues fixed with an acetic mixture were invariably blank as to granules in the cells of the islets. But with tissues fixed in aqueous-chrome-sublimate a most unlooked-for result appeared. The large cells of the islets which had been filled with violet granules in sections fixed with the other fluids were quite free from stained granules in the sections fixed with aqueous-chrome-sublimate, whereas, on the contrary, the cells which gave no violet reaction with the other fluids, in this one were filled with granules of a brilliant violet, while now it was the small groups of large cells that were colored with the yellow-brown of the orange $\mathrm{G}$ (Fig. 2).

From a consideration of these facts several conclusions arise. These conclusions have to do with the microchemistry of the cells of the Islets of Langerhans in the guinea pig's pancreas, and they may be stated romewhat as follows:

1. The Islets of Langerhans in the pancreas of the guinea pig consist of two types of cells: (a) a type containing a granular substance that is precipitated by alcohol of a strength of from 50 to 70 per cent; and, (b) a type, the granular content of which is precipitated by an aqueouschrome-sublimate fluid of the general character described.

2. The granular substance that is precipitated by alcohol is dissolved 
by the chrome-sublimate fluid, and the substance that is precipitated by the chrome-sublimate fluid is dissolved by alcohol.

3. Neither of these granular substances is of the same chemical character as the zymogen granules of the pancreas cell, and

4. Neither of them is of the same chemical character as the prozymogen of the pancreas cell.

To avoid cumbersome periphrase and repetition I will hereafter designate the cells in which the granules are fixed with alcohol as A cells, and these in which the granules are fixed with the chrome-sublimate fluid as $\beta$ cells.

That the chemical nature of the granules in the A cells differs from that of the granular content of the $\beta$ cells is borne out by the difference of the reaction of these substances to various fixing reagents non-alcoholic in character, and for the most part very simple in composition. The results follow:

Saturated Aqueous Sublimate.-With this fixation the islet cells act in virtually the same manner as with aqueous-chrome-sublimate, with the exception that the tissues are rather shrunken than the reverse. The A cells remain devoid of basic granules, the $\beta$ cells are very well preserved, and, throughout the whole of their cytoplasm, they are crowded with the violet granules, which are, however, not as brilliantly stained as in preparations fixed with aqueous-chrome-sublimate. The zymogen granules in the acini, on the contrary, are well fixed and react with a brilliant stain to the neutral gentian.

Saturated Picric Acid.-This fixation is poor, in a general way, and both types of islet cells are entirely devoid of granules, taking up only the plasma stain. The zymogen granules, here also, are sharply defined and stain well.

Nitric Acid, 10 per cent.-The general fixation is poor, but the acid seeks the A cells much in the same way as does alcohol, and the granules in them are well preserved. The $\beta$ cells, with this fixation, remain clear of granules altogether. So far as the A cells are concerned, the picture here presented is substantially the same as that obtained with the use of alcohol-chrome-sublimate and 70 per cent alcohol.

Formol, 10 per cent.-This fluid fixes the granules in the A cells, leaving the $\beta$ cells clear. Although the stain is by no means as brilliant as that obtained with the three principal fluids, yet the individuality of the granules in the A cells is capitally preserved. The zymogen granules in the pancreas cells are broken down and diffused.

Chromic Acid, 1 per cent.-In this fixation the granules in the A and 
$\beta$ cells both remain unfixed, and the islet appears uniformly brownish yellow. The zymogen granules, on the contrary, appear to be well fixed and react readily to the neutral gentian.

Aqueous-Chrome-Sublimate plus 5 per cent of 10 per cent cent Nitric Acid.-This fixation gives much the same result as that with aqueouschrome-sublimate, but the chromatic effects are not so clear. The $\beta$ cells are admirably picked out and almost invariably show the entire cytoplasm crowded with granules. In this fluid the zymogen granules are well preserved and take the stain fairly well.

The affinity of the two types of cells for certain fixing agents is peculiarly brought out in tissues fixed in a combination of these fluids. Thus in tissues fixed in chrome-sublimate solutions with equal parts of alcohol added, an islet here and there near the edge of the section shows both types of cells equally granulated; and the same is true of islets near the edge of sections from tissue fixed in aqueous-chrome-sublimate to which has been added 5 per cent of 10 per cent nitric acid.

These various tests, together with those furnished by the use of the three principal fluids above mentioned, enable us to make certain positive statements concerning the nature of the two substances contained in the $A$ and $\beta$ types of cells in the guinea pig's pancreas. That contained in the A cell is fixed by alcohol, by a 10 per cent solution of nitric acid, and by a 10 per cent solution of formol. In all these fixations it is stainable with Bensley's neutral gention. It is soluble in acetic acid, in saturated aqueous mercuric chloride, in non-alcoholic chrome-sublimate fluids, in these last-mentioned fluids also in the presence of nitric acid, in saturated aqueous picric acid, and in 1 per cent solution of chromic acid. The substance is chemically different from that in the zymogen granules, for in all these solutions the zymogen granule is fixed and remains stainable with neutral gentian, while on the contrary the zymogen granule is soluble in alcohol in which the A granules are well preserved.

The substance in the granule of the $\beta$ cell is fixed in aqueous saturated solution of mercuric chloride, in chrome-sublimate fluids in the presence of nitric acid, and in non-alcoholic chrome-sublimate fluids. It is soluble in alcoholic solutions, in acetic acid, in aqueous saturated solution of picric acid, in 10 per cent solution of formol, and in 1 per cent solution of chromic acid. And it differs chemically from the zymogen granule of the pancreas because the latter is uniformly fixed by thi above solutions with the exception of formol, in which it is not completely dissolved but only partially preserved.

These considerations go to show in contrast to Laguesse's theory that 
the substances contained in the granules of the $\mathbf{A}$ and of the $\beta$ cells are chemically different from the substance in the zymogen granule; and are different chemically from each other.

\section{Morphological Characters.}

Coincidental with these chemical differences are found certain differences in the morphological characters of the $\mathrm{A}$ and $\beta$ cells of the islets in the guinea pig's pancreas. The A cell is comparatively large and its nucleus is, for the most part, elliptical, although frequently it is circular (Fig. 1). It is markedly vesicular, strikingly large and vivid, and its chromatin content is very small. The chromatin is distributed in a few small, spherical masses, and this contributes, in section, to the lucid, vacuous, and prominent appearance of the nucleus of these cells. In some of the cells the granules are packed together throughout the entire cytoplasm and seem to lie directly against the nuclear membrane. In others the granules are determined in a mass bordering closely on the capillary, while the remainder of the cytoplasm is comparatively or completely free of them. The cells are polygonal and stand out in high relief against the lighter and yellowish back-ground formed by the mosaic of the $\beta$ cells. This is true only when the stain used is the neutral gentian of Bensley. The A cells can be chromatically distinguished only with great difficulty when other stains are employed-a fact struck out after trying a score or so of different basic dyes. Gentian violet, safranin, licht-grün, and other granule stains gave negative chromatic results, although the $a$ cells could be recognized by their conspicuous size even when the section was treated only with a plasma stain.

The $\beta$ type of cell appears, as a rule, considerably smaller and is, at the same time, vastly more numerous in the islet. Entire cords of them, uninterrupted by the presence of the A cells, appear in the picture, and almost invariably the cytoplasm of the entire cell is packed with the violet granules, which are uniformly distributed around the nucleus and which everywhere border on the capillaries. The nucleus of the $\beta$ cell is invariably centrally placed, is smaller than the nucleus of the A cell, circular, markedly less vesicular than the nucleus of the A cell, and is also distinguished from the nucleus of the A cell by the comparatively large quantity of chromatin it contains. In the nucleus of the $\beta$ cell the chromatin is frequently seen in the form of fine strands forming a network. In some of the islet cells there were found, indifferently as to either kind, a centrosome and, now and then, a mitotic figure. The cytoplasm consists of a delicate network. 


\section{Summary and Conclusions.}

Recapitulating the facts above described the following positive statements may be made:

1. In the Islets of Langerhans in the guinea pig's pancreas two types of cells, morphologically and physiologically distinct, are demonstrable. These cells show constant reactions to constant chemical tests. I have called these cells $\mathrm{A}$ and $\beta$ cells, respectively,

2. The granular content of the A cell differs chemically from that of the $\beta$ cell.

3. The granular contents of the A cell and of the $\beta$ cell, while differing chemically from each other, differ chemically from the granular content of the pancreas cell, and cannot, therefore, be identical with zymogen.

4. The granular contents of the $\mathbf{A}$ and of the $\beta$ cell differ chemically from the prozymogen manufactured by the pancreas cell as the antecedent of the zymogen granule of the pancreas cell.

5. The chemical and morphological differences between the $\mathbf{A}$ and the $\beta$ cell are correlated; that is, the relations between the anatomical and physiological characters of both types are found to be constant.

In drawing conclusions from these facts one is led to the conviction that the Islets of Langerhans are structures which in all probability have the function of producing a twofold substance which, poured into the blood stream, has an important effect upon metabolism. That this dual character of cell in the islet is constant throughout the entire class of mammals, if not throughout the entire phylum of vertebrates, is indicated as probable from the results of the comparative study now in progress, which I hope to make the subject of a future publication. The prospects seem to point to certain peculiar variations in the character of these cells in herbivora and carnivora, and to striking and highly suggestive variations among herbivora themselves.

While these results do not prove that pancreatic cells do not transform into islet cells, or vice versa, they furnish very strong reasons for holding that under normal conditions the islets are physiologically independent of the rest of the pancreas-a conclusion in accord with the observations of De Witt and Flint as to the framework and architecture of these structures, and with those of Opie, Pearce, and Helly as to the early differentiation in the embryo of the specific cells which are their histogenetic source.

It is but rational to conclude from the chemical evidence that the substances produced by the two types of cells of the islets are not to be classified with zymogen. If the cells of the pancreas have the power of 
transforming themselves into the cells of the islets which I consider improbable, that transformation must be regarded as a physiological as well as a morphological one. In the course of an examination of many hundreds of islets in the pancreas of the guinea pig I have been able to find but one example of what might be interpreted as a vestige of a lumen; and this singular structure seemed to be formed by cells of the $\mathbf{A}$ type.

There is one remaining aspect of the problem to be touched upon before closing. This is the possibility that the A and the $\beta$ types of cell are in reality two different phases of the same cell-a notion by no means improbable even in the face of the chemical evidence to the contrary. Professor Bensley, who has examined my preparations with considerable care, has pointed out cells which seem (from the anatomical side) to be intermediate between the two types, especially in certain preparations which, at his suggestion, were treated with Ehrlich's hæmatoxylin before they were submitted to the neutral gentian bath. But even granting the truth of this observation, the force of the general argument remains. If the $\mathbf{A}$ and $\beta$ cells are really phases of one and the same cellular structure, their different chemical characters suggest that they are engaged in the manufacture of two different secretions. If we conceive that the A cell changes into the $\beta$ cell, or vice versa, we must conclude that the change implies the taking on of a different physiological activity. Whether or not these two different secretions have to do with the pancreas itself or, through the pancreas with functions lying, in their special or general effects upon the chemistry of the body, near to or remote from, the pancreas, is a matter to be determined by further research.

I have to thank Professor Bensley, who was kind enough to direct my researches, for his lively interest in the work, for his invaluable suggestions as to technique, for his assistance in the interpretation of difficult nodi that arose as the work developed, and for having made preliminary reports of the work to the Association of American Anatomists. My thanks are also due to Mr. Leonard H. Wilder for the fidelity of the drawings which accompany this paper.

\section{LITERATURE.}

1. Benstex, R. R.-The Esophageal Glands of Urodela. Biological Bulletin, Wood's Holl, Vol. II, pp. 87-104, 1906.

2. Dale, H. H.-On the Islets of Langerhans in the Pancreas. Phil. Tr.; Lond., CXCVII, Bd., pp. 25-46, 1905.

3. DeWITT, L. M.-Morphology and Physiology of Areas of Langerhans in Some Vertebrates. Jour. of Exp. Med., New York, Vol. VIII, pp. 193-239, 1906. 
4. Dramare, V.-Studii comparativi sulle isoli di Langerhans de pancreas. Intern. Monatsschr. f. Anat. u. Physiol., Leipzig, Bd. 16, S. 155209, 1899.

5. Flint, Ḿ.-Das Bindgewebe der Speicheldrüsen und der Pankreas, etc. Arch. f. Anat. u. Entwicklngsgesch. Leipzig, Jahrg., 1903, S. 61-106.

6. Heuly, K.-Studien über Langerhansche Inseln. Arch. f. mikr. Anat. u. Entwicklngsgesch. Bonn., Bd. 76, S. 124-41, 1906.

7. Laguesse, E.-Sur la structure du pancréas chez quelques ophidiens et particulièrement sur les ilôts endocrines. Arch. d’Anat. Micr. Paris, 4, pp. 157-218, 1901.

8. Recherches sur l'histogenie du pancréas chez le mouton. J. de l'Anat: et Physol., Paris, T. 21, pp. 475-500, 1895.

9. LANE, M. A.-On the So-Called Transitional Cells of Lewaschew in the Islets of Langerhans. Proc. Associations of American Anatomists. Am. J. of Anat., Baltimore, Vol. V, No. 2, pp. XVI-XVII, 1906.

10. Langerhans, P.-Beiträge zur mikroskopischen Anatomie der Bauchspeicheldrüse. Inaug. Diss., Berlin, 1869.

11. Lewaschew, S. Uber eine eigentümliche Veränderung der Pankreaszellen warmblütiger Tiere bei starker Absonderungstätigkeit der Druse. Arch. f. mikr. Anat. u. Entwicklngsgesch. Bonn., Bd. 26, S. 453$485,1886$.

12. Mankowski, A.-Über die mikroscopischen Veränderungen des Pankreas nach Unterdinung einzelner Teile. Arch. f. mikr. Anat. u. Entwicklngsgesch. Bonn., Bd. 59, S. 286-294, 1902.

13. OPPEL.-Lehrbuch der Vergleichenden mikr. Anat der Wirbretier. Jena. III, pp. 800-818, 1900.

14. OPIE, E. L.-Disease of the Pancreas. (Lippincott) Phila., 1903.

15. The Histology of the Islands of Langerhans. Johns Hopkins Bull., Baltimore, Vol. VI, p. 117.

16. Pearce, R. M.-The Development of the Islands of Langerhans in the Human Embryo. Am. J. of Anat., Baltimore, Vol. II, pp. 445$455,1903$.

17. Renaut, J.-Sur les organes lymphoglandulaires et le pancréas de vertéBrés. Compt. rend. de l'Acad. de sc., Paris, T. 89, pp. 247-250, 1879.

18. Rennie, J.-The Epithelial Islets of the Pancreas in Teleostei. Quart. J. Micr. Sc. (New Series). Vol. XLVIII, pp. 379-405, 1905.

19. SaUerbeck, E.-Die Langerhanschen Inseln des Pankreas und ihre Beziehung zum Diabetes mellitus. Ergbn. der Alg. Path. u. Path. Anat. (Lubarsch. u. Ostertag) Wiesb. Abth. 2, S. 538-679, 1902.

20. Schulze, W.-Die Bedeutung der Langerhanschen Inseln im Pankreas. Arch. f. mikr. Anat. u. Entwicklngsgesch. Bonn., Bd. 56, S. 491$504,1900$. 
EXPLANATION OF FIGURES ON PLATE I.

Fig. 1. Section of an Islet of Langerhans of the Guinea pig, fixed in 70 per cent alcohol, stained with Bensley's Neutral Gentian, showing the A cells of the islet filled with intensely stained granules, $\beta$ cells orange. Zeiss apo. $2 \mathrm{~mm}$., oc. 8.

Fig. 2. Islet of Langerhans of the Guinea pig; aqueous chrome-sublimate fixation; neutral gentian stain; showing $\beta$ cells filled with minute violet granules; A cells orange, the staining reaction being reversed. Pancreatic acini, Pa. z. with zymogen granules are seen at the edges of the section. 
:

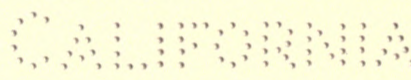




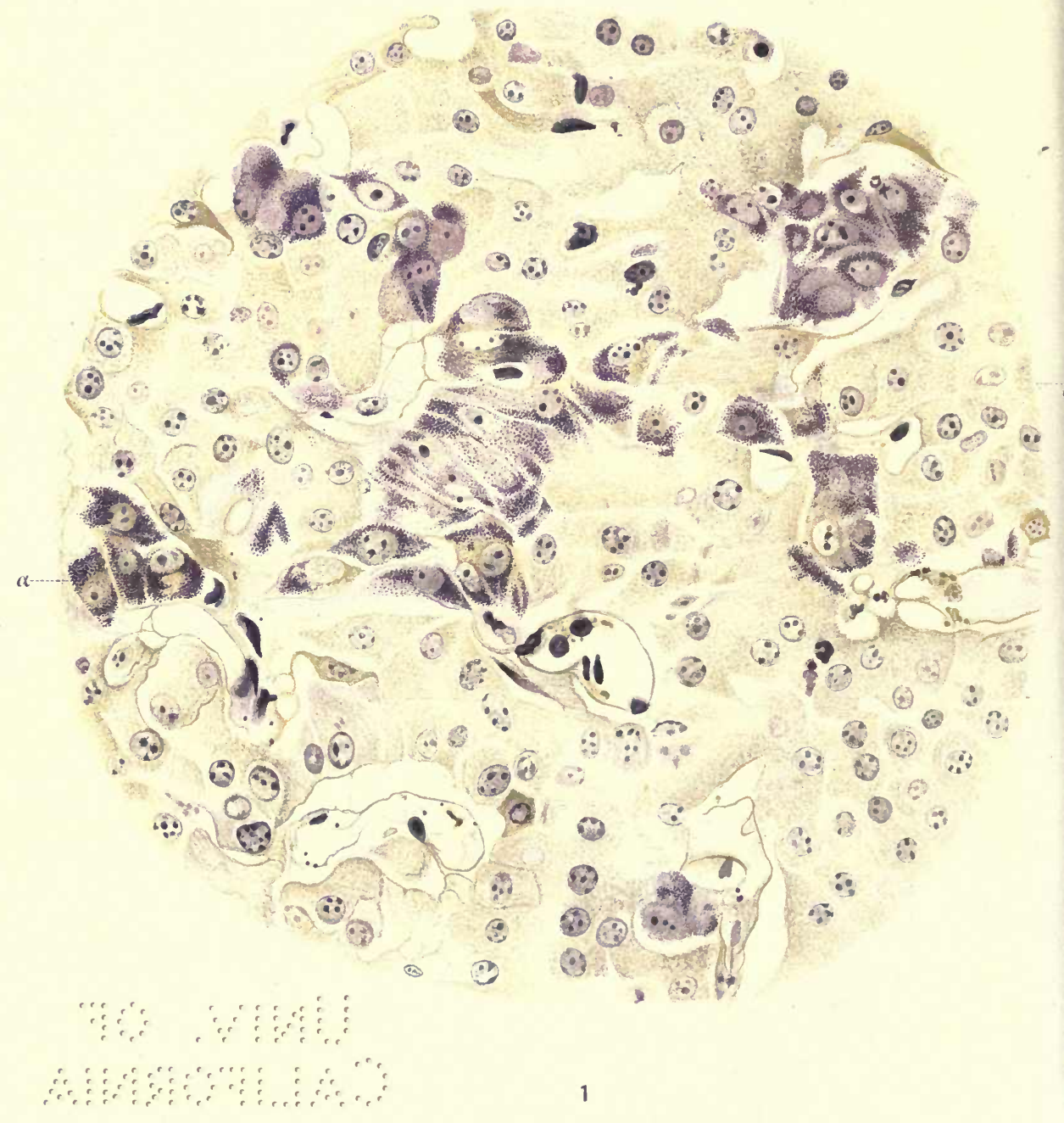




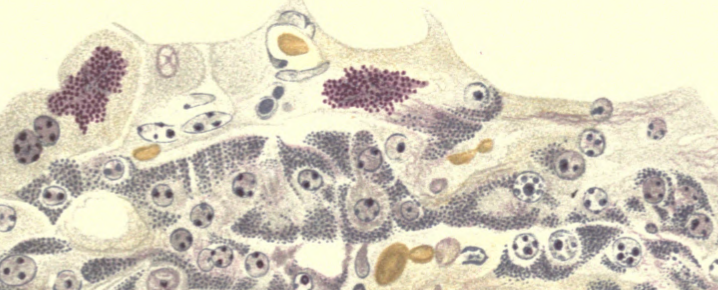

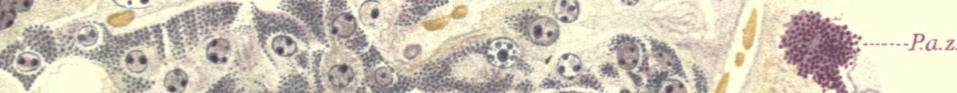

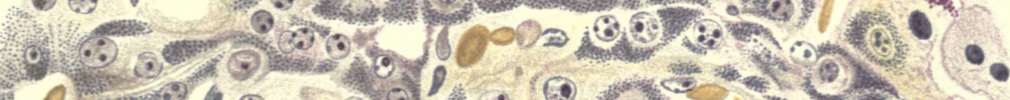

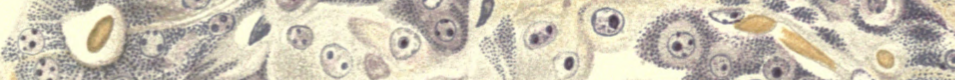

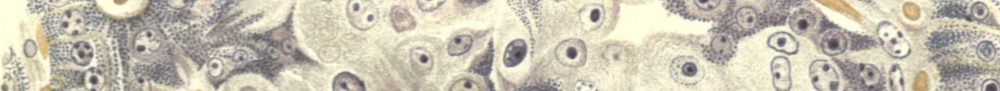

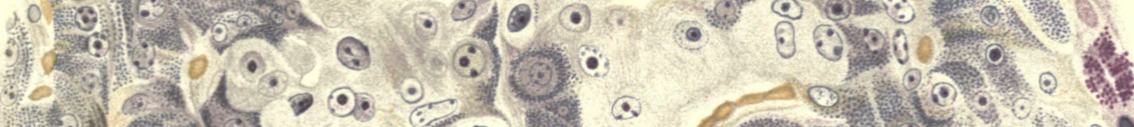

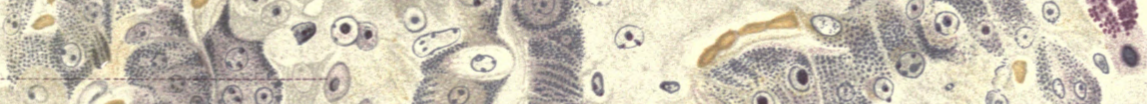

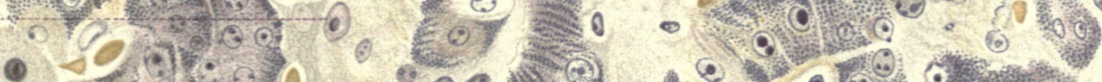

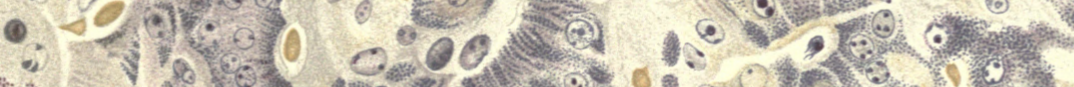
W.

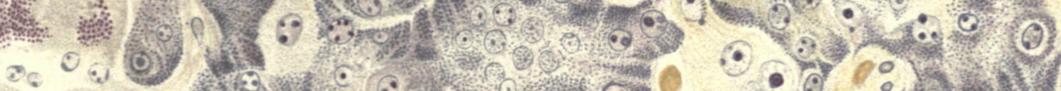

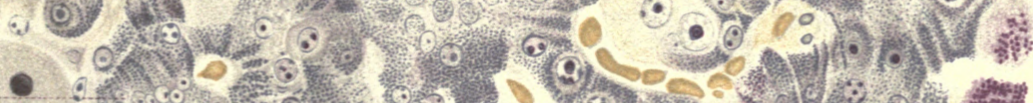

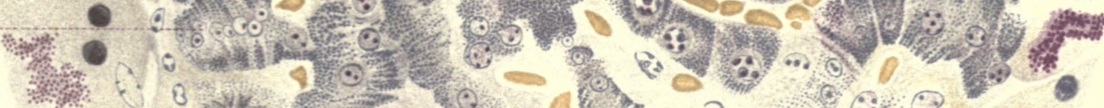

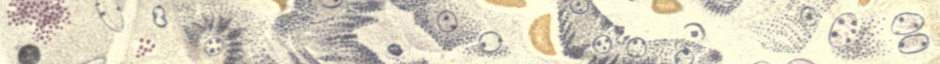

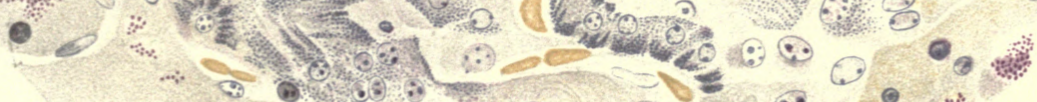

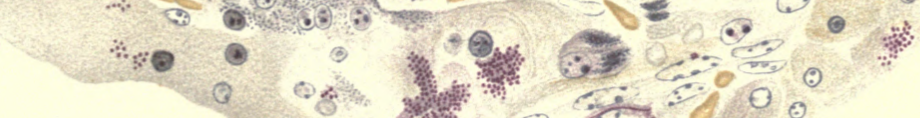
9 और 60

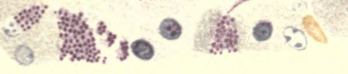


$\because \because \because \because \vdots$

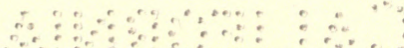








\section{DAY USE}

RETURN TO DESK FROM WHICH BORROWED

ic)

This book is due on the last date stamped below, or on the date to which renewed.

Renewed books are subject to immediate recall.

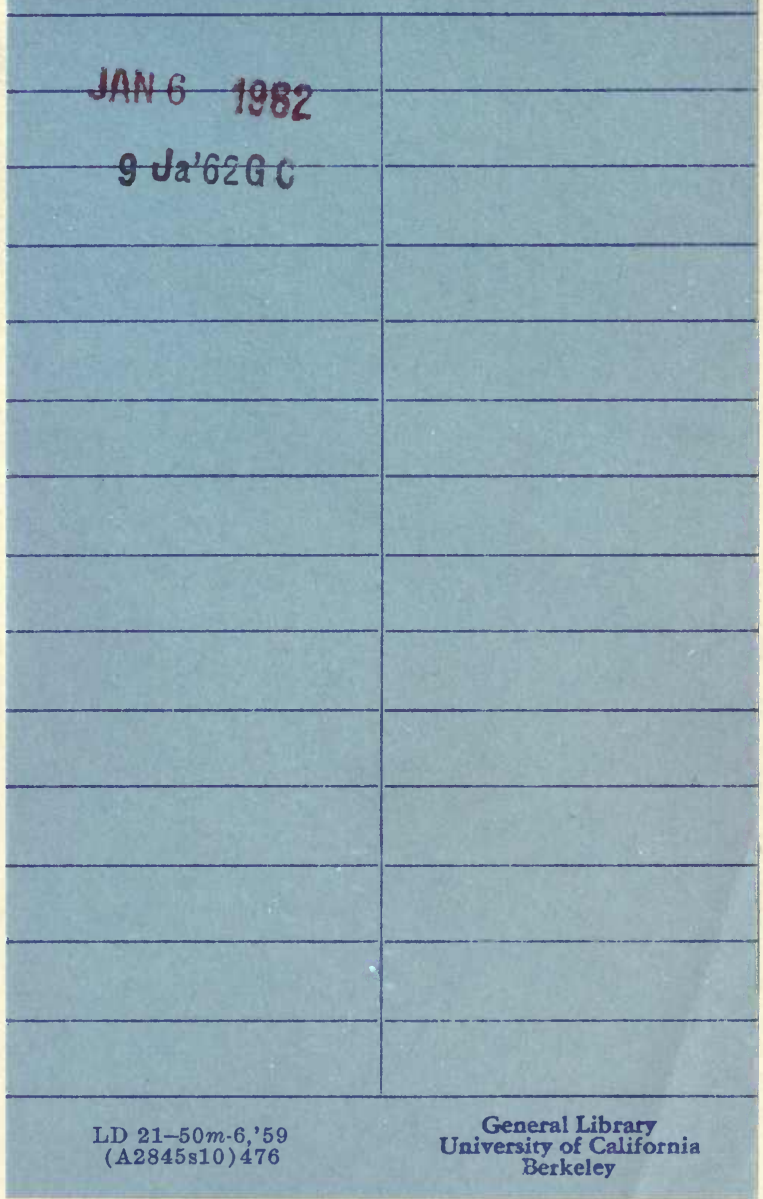



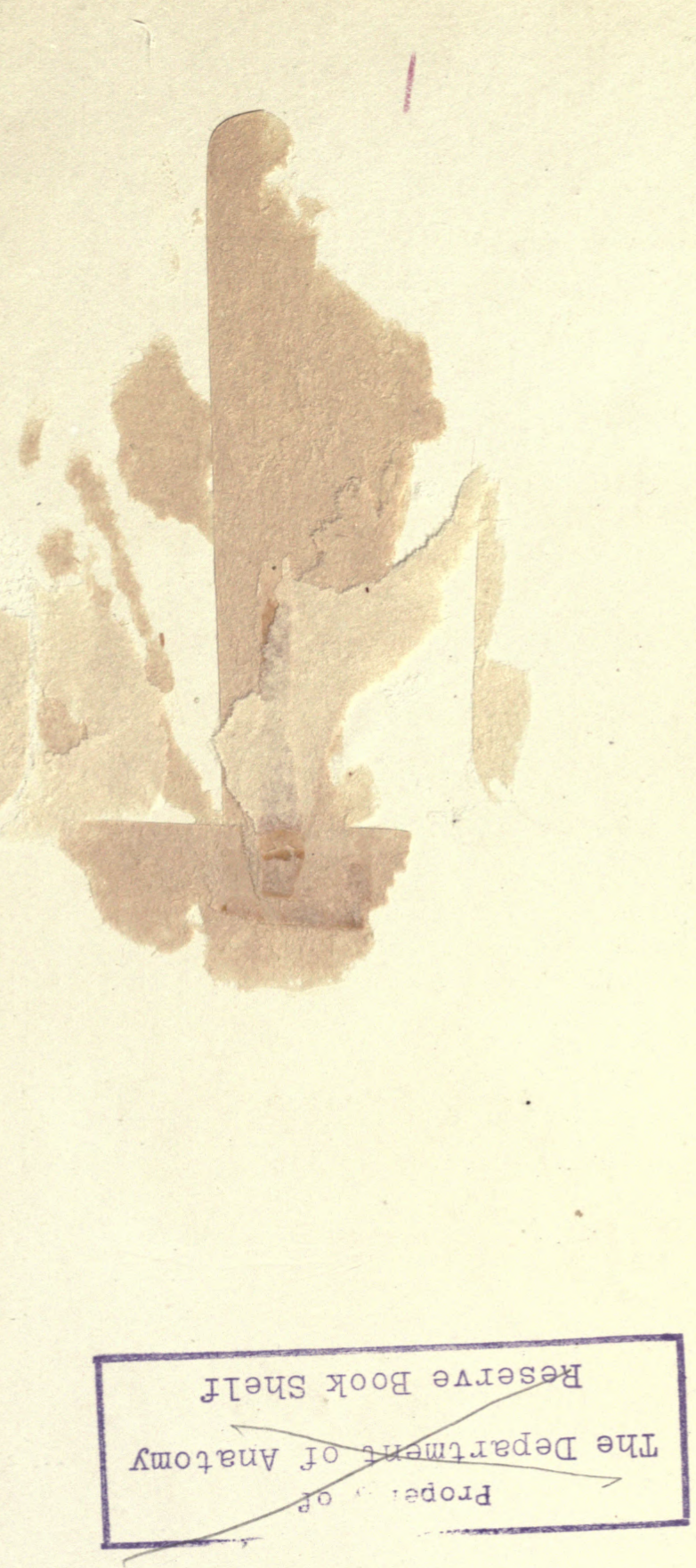
